\title{
The Impact of Electronic Mind Maps on Students' Reading Comprehension
}

\author{
Mohammad Mahmoud Talal Mohaidat ${ }^{1}$ \\ ${ }^{1}$ Department of English Language and Literature, King Saud University, Saudi Arabia \\ Correspondence: Mohammad Mahmoud Talal Mohaidat, Department of English Language and Literature, King \\ Saud University, Saudi Arabia. E-mail: mmohaidat@KSU.EDU.SA
}

Received: November 4, 2017

Accepted: March 10, 2018 Online Published: March 13, 2018

doi: $10.5539 /$ elt.v11n4p32

URL: http://doi.org/10.5539/elt.v11n4p32

\begin{abstract}
This study aimed to investigate the impact of the electronic mind map (IMindMap) on the development of reading comprehension among the ninth grade students in Jordan. The sample of the study consisted of two ninth grade sections from two public schools in Irbid First Directorate during the academic 2016-2017. Each section consisted of (30) students and the two sections were assigned randomly to an experimental group and a control group. The experimental group was taught the chosen texts using the Electronic Mind Mapping strategy while the control group was taught the same texts using the traditional method. The study data were collected using a reading comprehension test that was administered for both groups as a pre and a posttest. The statistical analysis showed a significant difference at the level of $(\alpha=0.05)$ between the mean scores of both groups in favor of the experimental group. Besides, the findings showed that the effect of applying the electronic mind maps in teaching reading texts was medium. Based on the findings of the study, a number of recommendations were made for both teachers and the Ministry of Education. The most notable recommendation was to train teachers in general and English teachers in particular on how to design electronic mind maps and apply them in their teaching practices.
\end{abstract}

Keywords: electronic mind maps, IMindMap, reading comprehension, information technology, methods of teaching English

\section{Introduction}

Reading is one of the most important skills a student must possess. It is considered the basis of all English language skills. It depends on several processes the most important of which is reading comprehension. Ortlieb (2013) considered reading comprehension as the ultimate goal of the reading process. It was also seen as the most mental skill that is connected with the learning process and as such directly affects the academic achievement and success in the different academic subjects. So, reading comprehension has become a field of study for different educational and psych-educational researchers. They studied all the factors that might hinder comprehension and the strategies that might contribute to its development.

Reading comprehension is a complex process associated with the brain. It requires linkage between the learning activities, the learner's experience and the learner's prior knowledge to form the meaning of a text. It also requires the formulation of mental images and visual perception of symbols and written words. Zeki (1993), Moore and Lo (2008), and Lipson and Wixton's (2009) discussed the visual images which are created inside the brain and pointed out that the brain creates a visual world and the process of seeing and understanding happen at the same time. So, the mind map, as a modern strategy, can accelerate learning and help students find knowledge easily through drawing a diagram that illustrate the main concepts and the main and sub-ideas. The mind map is also distinguished for its ability to quickly arrange ideas, fast learning and information recall (Buzan \& Buzan, 1996).

Psychologists and educators have different definitions of reading comprehension. Smith (1997) defined reading comprehension as an active process in which the learner's interprets the text and modifies it in a manner that suits his ability and his prior knowledge. Grellet (1995) defined it as the ability to comprehend the meaning of the written text and the ability to extract the main ideas efficiently. Lakshmi and Rao (2006) defined reading comprehension as understanding words and sentences in addition to the author's intended meaning regardless of the goal of reading, whether it is for professional knowledge, general information, or fun. Reading 
comprehension could finally be defined as using the prior knowledge to build the meaning of a text, (Lipson \& Wixson, 2009).

The process of reading comprehension depends on mental perception rather than sensory perception. Although it begins with the sensory perception of the written word, still, it requires concentration, attention, analysis of all elements as an integrated unit, (Al-Tal, 1992). In other words; it includes the reader's understanding of the meaning of the text, whether the explicit or implicit one. Durkin and Dolores (1995) mentioned that reading comprehension consisted of three main components:

1)-Understanding vocabulary: The reader must understand the vocabulary of the text and use his prior knowledge in extracting its meaning and explaining it.

2)- Understanding the sentence: The reader must understand the sentence and its relation to the preceding sentence. Of course, the learner's grammatical knowledge has a key role in understanding sentences.

3)- Understanding the paragraph: The reader must understand the sentences and their sequence and understand the relationships between them so that he can understand the text.

Reading comprehension includes a number of levels which follow a hierarchy. Higher level comprehension of texts depends entirely on the learners' success in understanding the low level ones. Researchers differed in classifying reading comprehension levels in terms of their number and names. But, a great similarity was observed among these classifications and the skills included. One of these classifications was the one introduced by Burns and Roe (2002) who classified reading comprehension to three levels:

1) Reading lines: It is the simplest level of comprehension achieved by the reader, where he understands the information and ideas of the text. This level is achieved when the reader understands what the author means in general even if he does not understand what the author wants in specific.

2) Reading between the lines: At this level the reader shows that he understands what the author specifically wants, and even goes beyond that by extracting meanings and relationships between ideas in the text and even explaining the meanings related to the theme of the text.

3) Reading behind the lines: At this level the reader uses the information included in the text and applies what he understands in similar situations to get new meanings and ideas.

It is not easy for the learner to acquire reading comprehension. On the contrary, it is a challenge for the teacher and costs him a lot of effort. This challenge becomes greater when teaching the learner a foreign language, (Casco, 2009). It empowers students to understand texts and extract ideas. In order to meet this challenge, the teacher has to use more effective strategies of teaching to improve students' reading comprehension in a foreign language. A number of researchers found that the use of mind maps in learning English as a foreign language is a very effective strategy in improving the level of reading comprehension among Students, (Siriphanich \& Laohawiryanan, 2010; Christodoulou, 2010; Liu, Chen, \& Chang, 2010; Kim \& Kim, 2012; Hofland, 2007).

Tony Buzan (2006) established the mind map strategy to enable learners arrange and classify ideas and tasks, and to improve reading, problem solving, and decision-making. Buzan's motivation for creating the mind map was his awareness of the educational systems which mainly focus on the employment of the left side of the brain. The left side of the brain is responsible for the use of logic, language, arithmetic, sequencing, and details of any topic. And there was a complete negligence to the right side which is responsible for using images, imagination, emotions, colors and a comprehensive view of different subjects, (Murley, 2007). Mind maps do have this facility, they employ both sides of the brain. Words, images and colors are the core for the preparation of these maps. The title is placed in the center, sub-ideas begin to diverge in all directions in a radiation sequence through what is called radiant thinking. This concept describes how the human brain treats various ideas and information, (Buzan \& Buzan, 1996; Siriphanic \& Laohawiriyano, 2010; Al-Jarf, 2009). This concept describes how the human brain deals with various ideas and information and links them with relationships using colors and images that refer to these ideas and using keywords for each concept. These are interconnected using curved links to keep the learner away from boredom and monotony. The strength of these links vary as we move away from the center, (Buzan, 2006).

Scientists have found that the brain consists of millions of Neutralism Cells which store information and data. The shape of these cells consists of the main center which has sub-links in the form of curvatures of gradual intensity which become weak whenever they move away from the center. Science shows that whenever the brain wants to store new information, these cells produce a new link, and are connected with the main subject to which that information is associated, or is linked with the prior knowledge which is already stored in the brain. This process was behind the emergence of the theory of learning (Christodoulou, 2010). Ausubel (1968) who is 
considered to be a pioneer of the theory of structuralism which stated that each learner possesses a unique sequence of learning experiences. When the learner receives information and knowledge from new learning situations, he linkes them to his prior knowledge in order to form a special perception and make a significant meaning.

Ausubel (1968) stated that learning depends on understanding the relationships, finding out principles and make a link between stimuli and responses. Understanding concepts and relationships must be built on organized strategies that make these concepts and relationships meaningful (Nashwati, 2003). When the learner links the new learning activities with his prior knowledge, then happens what Ausubel called, the meaningful learning. The success of this process depends on mental activities initiated by the learner towards the learning material, and how he organizes this material in a way that makes it meaningful and understandable (Al Zghoul, 2015).

The mind map is a type of graphic organizer. It is a visible drawing to what happens in the process of storing information in the brain, (Buzan \& Buzan, 1996). It is an important and a useful learning strategy as it helps learners to learn, write down their notes, and organize these notes effectively and easily retrieved, (Tucker, Armstrong, \& Massad (2010). The mind map is also an effective tool in helping low learners to improve their level of achievement (Holzman, 2004). It also improves cognitive processes and long-term memory of facts. Besides, it encourages using deeper levels of factual processes and better reorganizing the memory (Farrand, Hussain, \& Hennessey, 2002).

The traditional form of mind map is drawn by hand, but with the emergence of specialized software, the electronic mind maps started to appear, (Dara, 2010). The preparation of the e-mind map has become faster and more attractive. Some studies were conducted to compare between electronic mind maps and those drawn by hand and all these studies agreed that electronic mind maps have qualities that make them more efficient and more attractive as they include images, colors and drawings that attract the learner (Dara, 2010; Nong, Pham, \& Tran, 2009).

Several studies were conducted to investigate the impact of the mind map (electronic or traditional) on reading comprehension. They all agreed that mind maps have a positive effect on reading comprehension. Stankovic, Besic, Papic and Aleksic, (2011) conducted a study to assess the use of the mind map in teaching. They found that the mind map was the most powerful tool that could be used to improve reading comprehension as it enabled the learners to see the relations and links between the main ideas and the sub ideas in addition to the details and notes related to these ideas.

Peng (2011) conducted a study on the reading comprehension skill in which he found that e-mind map increased the level of reading comprehension because it combined the two parts of the brain. It connects between language, words, logical operations, and analysis from one side with creativity, images, construction and imagination from the other.

Benavides, Rivera and Rubio (2010) found that the e- mind map increased the reading comprehension level, increased achievement, facilitated editing of errors and easily changed design style among learners to bring it out in an appropriate way.

Siriphanich and Laohawiryanan, (2010); Liu, Chen and Chang, (2010); Kim and Kim, (2012); and Hofland, (2007) conducted studies on learners that learn English as a second language. They found that the use of the mind map was an effective strategy in improving the learners' reading comprehension level.

The study of Siriphanich and Laohawiryanan (2010) reached the same results. They explained how learners benefited from mind maps in improving their reading comprehension skills and also their joy while using them. Besides, they knew how to make the appropriate relationships between images and drawings. MalekZadeh and Bayat (2015) investigated the effect of using the mind map on understanding and comprehending the ideas in English texts. The study was conducted on students at one of the Iranian Universities. The findings revealed that the use of the mind map was very efficient in improving students' English reading comprehension. E-mind maps have proven their efficiency in developing reading comprehension skill among learners of English as a foreign language.

Gomez's and King's (2014) findings revealed that images, symbols and links in the mind maps helped the learners form connections between the vocabulary in the texts with these images and symbols. These factors were very effective in helping the learners understand the texts and recall the information better. The impact of the E-mind map is not limited to the direct improvement of reading comprehension, but it indirectly contributes to improve it (Ellozy \& Mustafa, 2010; Al-Jarf, 2009). Electronic mind maps developed critical reading skill, improved learners' writing in English, organized content, increased motivation towards learning English and 
developed the skill of reasoning and critical thinking, (Siriphanich \& Laohawiriyanon, 2010; Bidarra, Kommers \& Guimaraes, 2000).

It is noted that students are weak in learning the English language in general and are incapable of understanding the reading texts. This phenomenon is noticeable through the students' low achievement in English language and students' results in the General Secondary Certificate Examination in Jordan, (Alshourafa, 2012). The problem of this low achievement lies in some aspects: a- students do not know the meaning of the new vocabulary, bstudents could not summarize the content correctly, and c- they do not use efficient strategies that help them understand and comprehend the reading texts. Teachers focus on grammar and neglect the teaching of reading comprehension. This has a negative impact on students' ability in reading comprehension, (Al-Jamal, AlHawamleh \& Al- Jamal, 2013). Based on the advantages of the mind map and its positive effects on reading comprehension and the different aspects related to this process, this study was conducted to investigate the impact of the e-mind map on improving ninth grade students' reading comprehension in Jordan.

\section{Statement of the Problem}

Weakness among Jordanian students in the English language is noticeable. This weakness is evident in the low success ratio in this subject in the General Secondary Certificate Examination in Jordan. One of the possible causes of this weakness might be the low students' comprehension skill, which is the most mental skill related to achievement, (Al Tal, 1992; Guthrie \& Klauda, 2014).

According to Siriphanich and Laohawiriyanon (2010), students, who lack reading comprehension skills, find it difficult to understand the meaning of texts; identify the main idea or remember the details they have read earlier and connect them with the current thoughts. The researcher noticed that most students cannot link the new knowledge they get from reading with their previous knowledge.

The problem of the low level in the reading comprehension skill in the English language requires searching for effective teaching methods that use active learning, and utilize the learner's mental processes. To try solve the poor achievement in English, this study benefited from the overlap between modern technology and learning theories. This study used an advanced computer application, the Electronic Mind Mapping Program, to investigate the effect of its use in the different levels of reading comprehension: reading lines, reading between lines and reading behind the lines of English texts presented to the sample of the study compared to the effect of the traditional method found in the Teacher's Guide for the $9^{\text {th }}$ grade English curriculum in Jordan.

The study tried to answer the following question: Is there a significant difference at $(\alpha=0.05)$ between the mean scores of the experimental and control groups in the reading comprehension test which, is attributed to the use of electronic mental maps in the teaching of English language texts?

\section{Purpose of the Study}

This study aimed at finding out the effect of using electronic mind maps on the development of ninth grade students' reading comprehension in English Language, and compare this strategy with the traditional method of teaching based on the Teacher Guide assigned by the Ministry of Education in Jordan. It also aimed to reveal the size of the effect caused by the application of the electronic mind maps in understanding English texts.

\section{Significance of the Study}

This study derives its significance from the following:

1) Using the electronic mind map technique as an independent variable and studying its impact on reading comprehension of English language texts. This technique may contribute to encouraging English teachers to employ modern techniques in order to solve the problem of students' low achievement in reading comprehension in Jordan.

2) It is hoped that this study may enrich the Arabic library and the Arab educational literature with a new topic. The electronic mental map as a modern educational technique may help students understand texts in English and thus increase their academic achievement.

\section{Definition of Terms}

This study dealt with the following terms:

\subsection{Electronic Mind Maps}

It is a computer program used by the ninth grade students in the experimental group to help them analyze and organize ideas in order to understand English language texts using images, colors, gradient curves. Using this technique, students could insert images and colors to suit the main and sub ideas. These mental maps were 
designed using a special program: the (IMindMap), which was created by Tony Buzan. The researcher found this program on Buzan's official website for mental mapping. It can be downloaded from the website: www.thinkbuzan.com. This program's effect was measured by the grade achieved by the student in the reading comprehension test prepared by the researcher for the purpose of this study.

\subsection{The Traditional Method of Teaching}

It is the procedures and techniques available in the ninth grade English curriculum for the academic year 2016-2017 in the Jordanian schools, along with the Teacher Guide, which teachers have to use for planning and teaching in their classrooms.

\subsection{Reading Comprehension}

It is the individual's ability to understand the meanings, rephrase ideas and concepts in light of the prior knowledge he/she acquired from reading texts. Operationally, it is the comprehension of the reading texts available in the ninth grade English curriculum in Jordan which is measured from the grade the student achieved in the posttest prepared by the researcher for the purpose of this study.

\subsection{Action Pack}

It is the English language curriculum for the ninth grade in the Jordanian public schools during the year 2016-2017 which is adopted by the Jordanian Ministry of Education. Grade 9 students learn according to the general and specific objectives of the ninth series of Action Pack.

\section{Delimitations of the Study}

The results of this study were limited to the following:

1) This study was conducted on ninth grade male students in the public schools in Irbid First Directorate of Education. The sample of the study was selected in the first semester of the academic year 2016-2017.

2) The results were limited to the posttest, which was used to measure students' comprehension of an English text.

3) The test measures three levels of reading comprehension (reading lines, reading between the lines and reading behind the lines).

\section{Method and Procedures}

\subsection{Subjects of the Study}

The sample of the study consisted of grade-nine male students in Irbid First Directorate of Education in the northern region of Jordan. The number of male schools that contain ninth grade in this Directorate was (45) according to the Educational Statistics Department for the academic year 2016/2017. To randomly select a sample of two sections, the researcher used the list of schools (which contains the names of all schools that have ninth grade classes). He allotted a number for each school. He then followed a computer-generated table containing 2 numbers in between 1 to 45. The schools whose names are corresponding to the selected numbers were approached and investigated. The two schools were: Saad bin Abi Waqas Secondary School and Prince Al-Hassan Secondary School. Each school has three ninth grade sections. The two groups, control and experimental, were also chosen randomly from these 3 sections and each group consisted of (30) students.

\subsection{Instruments of the Study}

\subsubsection{The Electronic Mental Maps}

Three texts were selected from Action Pack 9: (The Science Fiction Story, People from the Past, And How the Egyptians Wrote). After studying the literature on mental maps, how to prepare them, analyzing the content of the lessons, and setting the objectives of each lesson, the concepts were specified, arranged sequentially, and then an electronic mental map was designed for each text.

To ensure the correctness and accuracy of the information contained in these maps, they were presented to four long-experienced ninth-grade teachers of English, and their observations contributed to improving their quality. These Mind maps were developed using the IMindMap software as follows:

1). Identifying main and sub topics, and the concepts and ideas related to them.

2). Drawing a shape in the middle of the page and writing inside it the main topic or subject of the text.

3). Drawing lines with different colors out of this shape according the number of sub-topics, wide at the beginning, and then curling until they are pointed at the end. At the top of each sub topic, the sub ideas were 
written.

4). Images and symbols that helped to create relationships and links between ideas were added. Figure 1 shows a model of mental maps that were used.

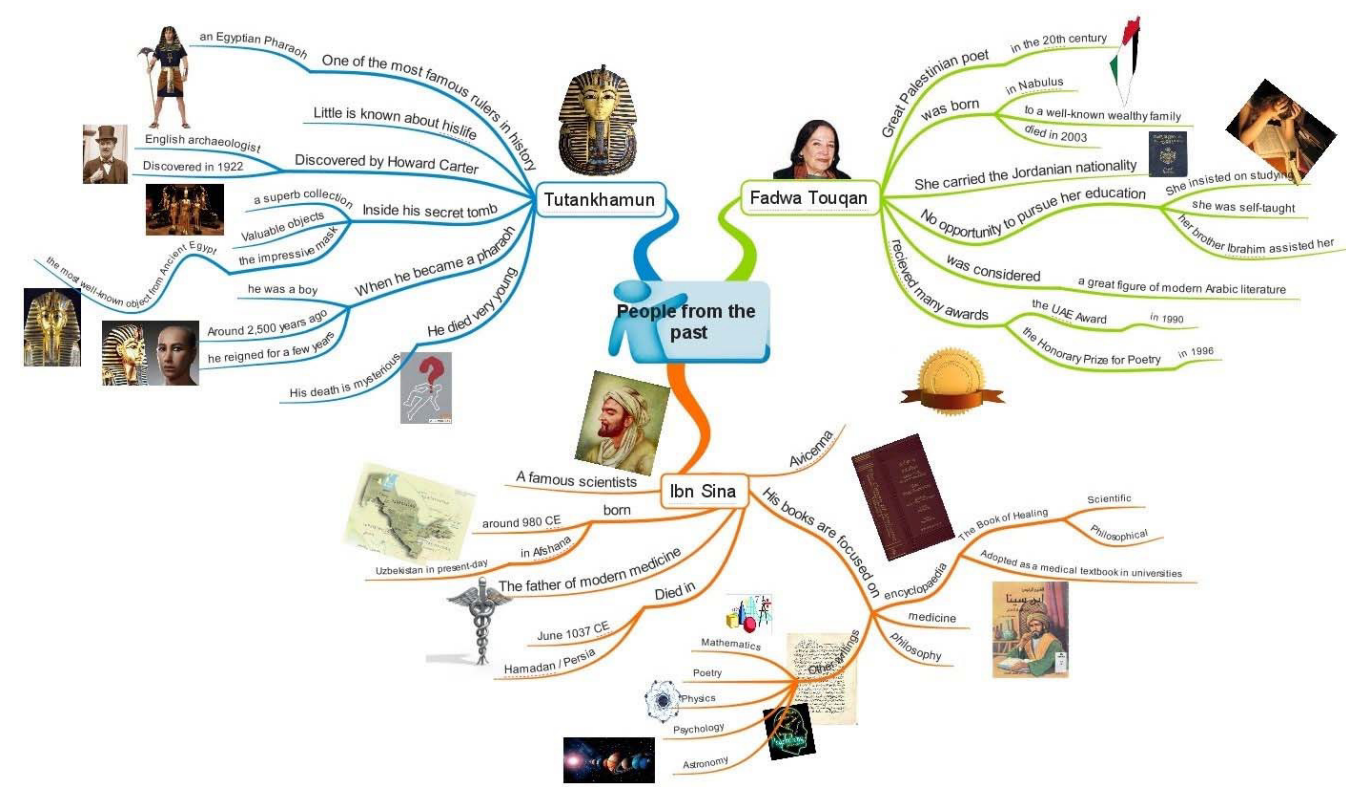

Figure 1. A sample of the electronic mental maps designed for one of the lessons

\subsubsection{The Reading Achievement Test}

The researcher prepared a reading comprehension test based on the texts taught for the study sample. It was used to verify the equivalence of the two groups before applying the experiment. The same test was administered as a post-test to measure comprehension of those texts. The following steps describe the construction of the reading achievement test, and its validity and reliability:

1) Referring to the English language textbook and grade 9 Teacher Guide, and extracting the main topics and sub-topics, which achieve the general and specific objectives of the reading texts.

2) Preparing the table of specifications and determine the relative weights of each text based on the number of objectives specified in the Teacher Guide.

3) Preparing test items in accordance with the three reading comprehension levels (reading lines, reading between lines, reading behind the lines). The test consisted of (35) multiple choice items of four options and one point was assigned for each item.

4 In order to check the validity of the test, it was given in its primary form (35 items) to a jury of five university professors specialized in English language teaching methods. The items of the test were judged according to the following criteria: Clarity of the items, their relevance to the three levels of reading comprehension, the relation of each item to the content of the reading text, and the linguistic clarity of each item. The jury also made amendments on the formation of some items, and suggested alternatives for them. All the amendments to the test items were made according to the jury's suggestions.

5) A pilot study was made to compute both of difficulty and discrimination coefficients. Two items were excluded due to their negative discrimination, and three more were excluded because of their difficulty since only $18 \%$ of students were able to answer them. For the rest of the test items, the difficulty coefficients ranged from $(0.33)$ to $(0.77)$, and the discrimination coefficients ranged from $(0.33)$ to $(0.80)$. These values were acceptable according to Kailani and Shrafeen (2011). The final draft of the test consisted of (30) items according to the three levels of comprehension: reading lines (10) items, reading between the lines (11), and reading behind the lines (9).

6) To establish reliability of the test, the test-retest method was used to find the Stability Coefficient. The test was applied on a sample of 30 students from the ninth grade at Hamza bin Abdu Elmutalib Preparatory School for Boys as a pilot sample. This school was selected because of being far from the schools of the sample of this 
study to avoid any kind of leakage of the test questions from the pilot sample.

The duration between the pre-and posttest was two months. The results of the test were then analyzed and Pearson correlation coefficient was calculated between scores of the two tests. The correlation between the two tests was (0.89) which is relatively high and this made the test suitable to measure the subjects' comprehension of the reading texts.

\section{Study Procedures}

To achieve the purpose of the study, the following steps were taken:

1) Administering the pre-test for both the control and experimental groups to ensure that the subjects' level in reading comprehension is equivalent. A comparison of the results of the two groups showed that there was no statistically significant difference $(\alpha=0.05)$ in the reading comprehension levels of the two groups.

2) A lesson plan for the three chosen texts was prepared. The lesson plans were in accordance with the Teacher Guide of English for the ninth grade and the electronic mental maps were used in teaching these lessons.

3) Creating the mental maps by using the IMindMap software.

4) The researcher trained the teacher of English (the one who taught the experimental group) in the summer holiday of the academic year 2016-2017 on how to use the (IMindMap) till he became proficient. This teacher held a two-hour training sessions the experimental group on the use and design of the computer mapping technology (IMindMap) and how to use them in different classroom situations.

5) Two teachers taught the texts to both groups, control and experimental, nine periods each. The experimental group was taught in the computer lab using (IMindMap) software, which was pre-installed on computers, but the control group was taught the chosen texts in class using the traditional method. After finishing teaching all the texts, the experimental group were put in pairs to prepare mental maps that showed understanding of the texts using (IMindMap).

6) After teaching the reading texts, the reading test was administered again as a posttest to measure students' achievement in both groups.

7) The answer sheets were corrected of both groups following an answer key which was prepared for this purpose. The test consisted of (30) multiple choice items, one mark for every correct answer and zero for the wrong answer. The total score ranged from (0 to 30$)$.

\section{Study Design}

This is a quasi-experimental study based on a control and experimental groups. A pre-test was administered to the groups before the study started. The control group was not subject to any treatment. They were taught the texts using the traditional method. Meanwhile, the experimental group studied the same texts using the electronic mind mapping technique (IMindMap). The test was administered again as a post-test to the two groups and results were analyzed.

\section{Findings of the Study}

The study attempted to answer the following question: Is there a statistically significant difference at the level $(05.0=\alpha)$ between the mean scores of both groups in the reading test that can be due to the use of (IMindMap) in teaching the English texts?

To answer the question, the mean scores and standard deviation of student's scores in the posttest and the (T) value were calculated as shown in table (1).

Table 1. The mean score and standard deviations of the scores of the experimental and control groups in the pre and posttest

\begin{tabular}{llllllll}
\hline $\begin{array}{l}\text { Pretest } \\
\text { Group }\end{array}$ & Number & $\begin{array}{l}\text { Mean } \\
\text { score }\end{array}$ & $\begin{array}{l}\text { Standard } \\
\text { Deviation }\end{array}$ & $\begin{array}{l}\text { Posttest } \\
\text { sean } \\
\text { score }\end{array}$ & $\begin{array}{l}\text { Standard } \\
\text { Deviation }\end{array}$ & Mean score & $\begin{array}{l}\text { Standard } \\
\text { Error }\end{array}$ \\
\hline Control Group & 30 & 14.833 & 2.94 & 17.233 & 3.18 & 17.312 & 0.54 \\
$\begin{array}{l}\text { Experimental } \\
\text { Group }\end{array}$ & 30 & 15.167 & 3.21 & 19.667 & 3.31 & 19.588 & 0.54 \\
\hline
\end{tabular}


Table 1 shows that the mean score of the experimental group were higher than the control group. In order to investigate the level of significance of the differences, an analysis of covariance was made. Table (2) shows the results of this analysis.

Table 2. The results of the covariance analysis of the experimental and control groups performance on the post-achievement test

\begin{tabular}{|c|c|c|c|c|c|c|}
\hline $\begin{array}{l}\text { Source of } \\
\text { variance }\end{array}$ & $\begin{array}{l}\text { Sum } \\
\text { squares }\end{array}$ & $\begin{array}{l}\text { Degree of } \\
\text { Freedom }\end{array}$ & $\begin{array}{l}\text { Mean } \\
\text { Squares }\end{array}$ & (F) value & $\begin{array}{l}\text { Statistical } \\
\text { significance }\end{array}$ & $\begin{array}{l}\text { Practical } \\
\text { Significance }\end{array}$ \\
\hline Pretest & 77.508 & 1 & 121.237 & 14.080 & 0.000 & 0.198 \\
\hline Group & 121.237 & 1 & 77.508 & 9.002 & 0.004 & 0.136 \\
\hline Error & 490.797 & 57 & 8.610 & & & \\
\hline Total & 700.850 & 59 & & & & \\
\hline
\end{tabular}

The results of the covariance analysis in Table 2 indicated that there was a statistically significant difference $(\alpha=$ 0.05 ) between the experimental and control groups. After making a comparison between the mean scores, this difference was in favor of the experimental group. This indicated that using the electronic mind maps had led to a higher comprehension among the experimental group than the control group who used the traditional method.

As for the size of the effect, the value of ( $\eta 2)$ was calculated and it was $(0.1267)$. This value reflected that the power of the relationship was medium based on the total variance of the independent variable of the sample when the IMindMap was used. The Delta value $(\Delta)$ was $(0.751)$. According to Kailani \& Shraifeen (2011), this value was considered of medium effect This value was very close to the level of the significant effect since the effect was considered medium when $\Delta$ (d) ranges between $(0.50-0.70)$, and it is considered significant when $\Delta(\mathrm{d})$ is $\geq(0.80)$.

\section{Discussion and Recommendations}

The results of the study showed a statistically significant difference between the mean scores of the control and experimental groups in the reading comprehension post-test in favor of the experimental group. The positive impact of the experimental group's development in reading comprehension might be attributed to the use of the electronic mind maps in understanding the texts, analyzing them, and understanding the main and sub ideas. In addition, the easy insertion of images, shapes, and the use of colors in making the electronic mind maps in a creative computerized environment, and the representation of the ideas, which are written in abstract words, in a picture form are based on the brain hemispheres; words and figures in the left hemisphere, images and colors in the right one (Siriphanich \& Lohawiriyanon, 2010; Berg, 2011). Since there was an agreement that the mind map works in the same way the brain works, its use had stimulated the use of the two hemispheres. Ideas were arranged in a sense that helped the brain to read and remember the information rather than the traditional linear thinking. It also helped the experimental group students developed strategies which helped them analyze, arrange and construct ideas which improved their reading comprehension skills.

Besides, the significant progress of the experimental group might be attributed to the fact that students often show positive attitudes toward new teaching methods and techniques that keep them away from boredom and monotony of the traditional class. Trevino (2005), Al-Jarf, (2009) and Hourani (2011) discussed the use of mental maps as an educational technique in many school subjects and found that the use of these maps created positive attitudes towards learning these subjects, especially the use of electronic mental maps is simple. They also added that working on these maps in the computer lab created a competitive atmosphere among students, who showed their skills in making these mind maps. Designing these maps showing the ideas in the given texts indicated a better understanding of these texts.

The significant difference between the experimental group and the control group can be explained by the fact that the experimental group learned in a way that helped them speed up their learning process and find knowledge faster by drawing out a diagram that illustrates the basic concept of the main and sub ideas. In contrast, members of the control group learned in the traditional way that focused on preserving and memorizing information. Besides, the increase of students' understanding may be due to the fact that electronic mind maps link the texts' ideas with drawings, colors and tangible objects, which concentrates information in students' minds. Using mind maps fosters the use of both hemispheres of the brain as they combine the written 
information with drawings and symbols. In addition, the use of mind maps is consistent with the constructivist theory which describes knowledge as an activity that is constructed by the learner.

The results of this study were consistent with the findings of Ralston and Cook (2007), whose study aimed to find out the impact of IMindMap in the organizing students' ideas and the way they are displayed. Their study showed that IMindMaps increased students' concentration in organizing ideas and displaying information clearly and attractively. The results of this study were also consistent with the results of Al-Jarf, (2009) and Zhou (2016) which showed that the use of the IMindMaps provided a successful way to develop the students' ability to generate and organize the ideas which they use in their writings and it also developed their positive attitudes toward the program itself.

The results of the study were also in line with the results of Peng's study (2011) which showed an increase in the experimental group's achievement in reading comprehension due to the use of mental maps that were connected to e-books, which stimulated students' motivation. In addition, the study findings were consistent with the results of the Moi and Lian (2007) who proved that students were able to retrieve answers effectively from the mental map, understand reading texts better and recall information and thus understand texts better and faster.

Other studies such as Siriphanich and Lohawiryanan, (2010) were also in line with the results of this study. Their study revealed the use of the mental mapping technique has caused a positive effect on the students' reading comprehension and they suggested to use this technique in teaching reading texts to increase students' level of comprehension. The results of this study showed an increase in the mean scores of the experimental group due to the use of electronic mental maps. This increase might be due to the fact that the mental maps are efficient in strengthening memory and increasing students' ability to easily retrieve information, facts and ideas by translating texts into comprehensible visual forms. They also helped students distinguish important information, connections among pieces of information, and shape students' cognitive structure (Tucker, Armstrong, \& Massad, 2010).

The medium effect size of using the electronic mind maps by the students of the experimental group may be attributed to the fact that the computer has allowed students to work on mental maps simultaneously. This enabled them to share their experiences, and enhanced their imaginative skills which enriched the maps they prepared. This is consistent with the findings of Goodnough and Woods' (2002). They showed that the mind mapping technology provided students with the opportunity to be creative in the making these maps. They used the color options, symbols, images and keywords in their designs. The experimental group has also dealt with the mental mapping technique as a means of learning through playing; it was an encouraging and fun way to learn.

In general, and based on the findings of this study and the findings of most of the reviewed studies, mind maps have proven their effectiveness in activating memory, raising the level of understanding of reading texts, and increasing their efficiency in organizing ideas and presenting them to others. Mind maps also increased students' self-confidence about their learning as they could depend on the information which they could retrieve from the brain in a fast and organized way, and thus rephrase, rearrange this information in a manner that shows their understanding (Chen \& Chang, 2010; Kim \& Kim, 2012).

\subsection{Recommendations}

In the light of the findings of the study, the following recommendations were made:

1) Conducting workshops on how to prepare and apply the electronic mind mapping technique and urge teachers of English to attend these workshops and train them how to use it in teaching of English language skills at different levels.

2) Conducting further studies that investigate the impact of electronic mind maps on other English language skills.

\section{Acknowledgement}

The researcher expresses his deepest thanks and gratitude to the Deanship of Scientific Research and the Research Center at the Faculty of Arts (King Saud University, Saudi Arabia) for funding this research.

\section{References}

Al-Jamal, D., Al-Hawamleh, M., \& Al-Jamal, G., (2013). An Assessment of Reading Comprehension Practice in Jordan. Jordan Journal of Educational Sciences, 9(3), 335-344.

Al-Jarf, R. (2009). Enhancing Freshman Students' Writing Skills with a Mind Mapping software. Paper presented at the 5th International Scientific Conference, eLearning and Software for Education (9-10 April 2009). Bucharest. 
Al Kailani, A., \& Shraifeen, N. (2011). Madkhal ila Albahth fi Eluloom Al Tarbawia Walijtimaia: Assasiatoh Wamanahijoh Watasameemoh Wasaleeboh Al Ihsaiah, Dar Al Masirah, Amman, Jordan.

Alshourafa, A. (2012). The effect of motivation on Jordanian 10th grade students' writing skills in English. European Scientific Journal, 8(22), 235-247.

Al Tal, S. (1992). Athar El Surah Al Qiraiya Wa Mustawa El Maqroiya Wal Jins fi Elisteaab ElQirai' Li Talbat El Saf El Thamin. Abhath El Yarmuk, Silsilat Al Ulum El Insania, 8(4), 9-44.

Al Zghoul, E. (2015). Mabade’ Elm El Nafs El Tarbawi, V(6), Dar El Masira Lilnasher Waltawzee', Amman, Jordan.

Ausubel, D. (1968). Educational psychology: a cognitive view. New York: Rinehart and Winston. https://doi.org/10.1080/00461526809528961

Benavides, S., Rivera, F., \& Rubio, M., (2010). Improving reading comprehension skills by using mind -mapping software with students of bachelor's degree in English attending reading and writing in English II course. (Master thesis) Universidad de Oriente UNIVO. San Miguel, El Salvador.

Berg, H. (2011). How to use mind-mapping to improve reading comprehension. Retrieved August 2, 2017, from Mapping-to-Improve-Reading- Comprehension \& id=5761817.

Bidarra, J., Guimarães, N., \& Kommers, P. A. M. (2000). Handling hypermedia complexity: Fractal hyperscapes and mind-mapping. Paper presented at the eighth ACM Multimedia Conference, Los Angeles.

Burns P., \& Roe. B. (2002). Informal reading inventory. Boston: Houghton Mifflin.

Buzan, T., \& Buzan, B. (1996). The mind mapping book: How to use Radiant Thinking to maximize your brain's untapped potential. London: BBC.

Buzan, T. (2006). Mind Maps for Kids: An Introduction. Harper Thorsons, Hammersmith, London.

Casco, M. (2009). The Use of "Mind Maps" in the Teaching of Foreign Languages. XXXV FAAPI Conference Proceedings. Bahía Blanca.

Christodoulou, K. (2010). Collaborative on-line concept mapping. (Master's thesis). University of Manchester. UK.

Dara, C. (2010). Hand Drawing Vs. Using Software Mind Mapping. Retrieved July 21, 2017 from, $\mathrm{http} / / / \mathrm{www}$.isoftwarereviews.com/hand-drawingvs- using-software-mind-mapping

Durkin, A., \& Dolores. (1995). Teaching them to Read. New York: Allyn Bacon Company.

Ellozy A., \& Mostafa, H. (2010). Making learning visible: using e-maps to enhance critical reading skills. MERLOT Journal of Online Learning and Teaching, 6(3) 634-46.

Farrand, S., Hussain, F. \& Hennessy, E. (2002). The efficacy of the mind map study technique. Journal of Medical Educational, 36(5), 426-431. https://doi.org/10.1046/j.1365-2923.2002.01205.x

Gómez, M., \& King, G. (2014). Using mind mapping as a method to help ESL/EFL students connect vocabulary and concepts in different contexts. TRILOGíA. Ciencia, Tecnologíay Sociedad, 10, 69-85.

Goodnough, K., \& Woods, R. (2002). Student and teacher perceptions of mind-mapping. The Annual Meeting of American Educational Research Association. (1st to 5th April 2002), New Orleans.

Grellet, F. (1995). Developing reading skills: A practical guide to reading comprehension exercises. London: CUP.

Guthrie, J., \& Klauda, S.L. (2014). Effects of classroom practices on reading comprehension, engagement, and motivations for adolescents. Reading Research Quarterly, 49(4), 387-416. https://doi.org/10.1002/rrq.81

Hofland, C. (2007). Mind-mapping in the EFL classroom. Fontys Hogescholen: Fontys Teacher Training College Sittard.

Holzman, S. (2004). Thinking maps: Strategy-based learning for English language learner. Annual Administrator Conference 13th Closing the Achievement Gap for Education Learner Student, Sonoma County Office of Education, California Department of Education.

Hourani, H. (2011). Athar Istikhdam Al-Khara'et Al-Thihniyyah fi Tahseel Talabat Al-saff Al-tase' fi maddat Al-Uloum wa fi Etijahatihim nahwa al-uloum fi Al-madares Al-hokoumiyyah fi Madinat Qalqeelyah, Nablus. Al-Najah National University. 
Kim, S. Y., \& Kim, M. R. (2012). Kolb's Learning Styles and Educational Outcome: Using Digital Mind Map as a Study Tool in Elementary English Class. International Journal for Educational Media and Technology, 6(1), 4-13.

Lakshmi, L., \& Rao, D. (2006). Reading and Comprehension. New Delhi: Discovery Publishing House.

Lipson, M., \& Wixson, K. (2009). Assessment and instruction of reading and writing difficulties, an interactive approach (4th Edition) Pearson Boston.

Liu, P. L., Chen, C. J., \& Chang, Y. J. (2010). Effects of a computer-assisted concept mapping learning strategy on EFL college students' English Reading Comprehension. Computers \& Education, 54(2), 436-445. https://doi.org/10.1016/j.compedu.2009.08.027

Malekzadeh, B., \& Bayat, A. (2015). The Effect of Mind Mapping Strategy on Comprehending Implicit Information in EFL Reading Texts. International Journal of Educational Investigations, 2(3), 81-90.

Moi, W., \& Lian, O. (2007). Introducing Mind Map in Comprehension. Educational Research Association, Singapore. Retrieved October 7, 2017, from http://conference.nie.edu.sg/2007/paper/papers/ LAN469.pdf

Moore, C., \& Lo, L. (2008). Reading comprehension strategy: Rainbow dots. The Journal of the International Association of Special Education, 9(1), 124-127.

Murley, D. (2007). Mind-mapping complex information. Illinois: Southern Illinois University School of Law Library.

Nashwati, A. (2003). Elm El Nafs El Tarbawi, V(4), Dar El Forqan, Amman, Jordan.

Nong, B., Pham, T., \& Tran, T. (2009). Integrate the digital mind-mapping into teaching and learning psychology. Teacher Training Component - ICT. Vietnam

Ortlieb, E. (2013). Using Anticipatory Reading Guides to Improve Elementary Students' Comprehension. International Journal of Instruction, 6(2), 145-162.

Peng, S. (2011). The effect of combining mind map and electronic picture-books on fourth-graders' reading comprehension ability and reading motivation. (Master's thesis). Taiwan: National Pingtung University of Education.

Ralston, J., \& Cook, D. (2007). The use of IMindMap: A tool of exploration and presentation. Think Buzan. Retrieved October 12, 2017, from http://www.thinkbuzan.com/uk/aricles/mindmappingworks

Siriphanich, P., \& Laohawiriyanon, C. (2010). Using Mind Mapping Technique to Improve Reading Comprehension Ability of Thai EFL University Students. A paper presented in the 2nd International Conference on Humanities and Social Sciences April 10th, 2010 Faculty of Liberal Arts, Prince of Songkla University strategic teaching Retrieved June 25, 2017 from http://fs.libarts.psu.ac.th/research/conference/Proceedings2/article/4pdf/001

Smith, C. B. (1997). Vocabulary instruction and reading comprehension. ERIC Digest, ED 412506.

Stankovic, N., Besic, C., Papic, M., \& Aleksic, V. (2011). The evaluation of using mind maps in teaching. Technics Technologies Education Management, 6(2), 337-343.

Trevino, C. (2005). Mind-mapping and outlining: Comparing two types of graphic organizers for learning seventh-grade life science. (Unpublished Ph.D. thesis). USA: Texas Tech University.

Tucker, J. M., Armstrong, G. R., \& Massad, V. J. (2010). Profiling the mind map user: A descriptive appraisal. Journal of Instructional Pedagogies, 2(4), 1-13.

Zeki, S. (1993). A Vision of the brain. London. Oxford Blackwell Scientific Publication.

Zhou, S. (2016). Scaffolding Chinese College Students' English Learning through Mind Mapping. International Journal on Studies in English Language and Literature (IJSELL), 4(1), 31-35.

\section{Copyrights}

Copyright for this article is retained by the author(s), with first publication rights granted to the journal.

This is an open-access article distributed under the terms and conditions of the Creative Commons Attribution license (http://creativecommons.org/licenses/by/4.0/). 